\title{
The Effects of Conformational Constraints in the Polyamine Moiety of Philanthotoxins on AMPAR Inhibition
}

\author{
Henrik Franzyk ${ }^{[b]}$, John W. Grzeskowiak ${ }^{[a]}$, Denis B. Tikhonov ${ }^{[c]}$, Jerzy W. \\ Jaroszewski[b], and lan R. Mellor ${ }^{\star[a]}$
}

Philanthotoxin-433 (PhTX-433) is a known potent inhibitor of ionotropic glutamate receptors and analogues have been synthesized to identify more potent and selective antagonists. Here, we report on the synthesis of four PhTXs with a cyclopropane moiety introduced into their polyamine chain, and on their inhibition of an AMPA receptor subtype by using two-electrode voltage-clamp on Xenopus oocytes expressing the GluA1flop subunit. All analogues were more potent than PhTX-343 with trans-cyclopropyl-PhTX-343 being the most

\section{Introduction}

Philanthotoxin-433 (PhTX-433, 1; the numerals indicate the number of methylene groups spacing the nitrogens in the polyamine moiety; Figure 1) is a toxin found naturally in the venom of the solitary wasp, Philanthus triangulum. ${ }^{[1,2]} \mathrm{PhTX}-433$ and many of its synthetic analogues have been shown to have non-competitive inhibitory effects at both ionotropic glutamate receptors and nicotinic acetylcholine receptors. ${ }^{[3-6]}$ In that respect $\mathrm{PhTX}$ are attractive molecules to investigate further given that both of these receptor types are accepted as valid drug targets for a variety of neurodegenerative and other disorders of the central nervous system. ${ }^{[7]}$ The modular butyryl-tyrosylthermospermine composition of $\mathbf{1}$ has allowed for efficient generation of many synthetic analogues demonstrating the importance of all of these structure segments. ${ }^{[4,6,8-11]}$ PhTXs 1, 2 and an array of other analogues have been shown to produce powerful voltage-dependent inhibition of a-amino-3-hydroxy-5methyl-4-isoxazolepropionic acid receptor (AMPAR) currents suggesting a binding mode with the polyamine inserted deeply within the pore region of the ion channel. ${ }^{[3]}$ This hypothesis is supported by the observation that AMPARs containing the GluA2 subunit with arginine at the "Q/R" site in the selectivity filter of the pore exhibit drastically reduced inhibition by PhTX-343 and other polyamine-containing molecules. ${ }^{[12]}$

In the last two decades advanced methodologies for solidphase synthesis (SPS) of polyamines have been developed, ${ }^{[13]}$ however, no examples of SPS of cyclopropane-containing polyamine derivatives have been reported. The commonly used solution-phase method for obtaining polyamines displaying a cyclopropane moiety is alkylation of mesitylenesulfonamides with mesitylenesulfonates of cyclopropane diols, but this is not readily transferred into an SPS protocol due to the harsh conditions potent ( 28-fold) and cis-cyclopropyl-PhTX-343 least potent ( 4-fold). Both cis- and trans-cyclopropyl-PhTX-444 had intermediate potency (both 12-fold). Molecular modelling indicates that a cyclopropane moiety confers a favourable steric constraint to the polyamine part but this is compromised by a cis conformation due to enhanced intramolecular folding. Elongated PhTX-444 analogues alleviate this to some extent but optimal positioning of the amines is not permitted.

required for deprotonation of the sulfonamide and the risk of cross-linking the resin due to the bifunctional building block. ${ }^{[14]}$ Cyclopropane-trans-1,2-dicarboxylic acid ${ }^{[15]}$ may be readily obtained from the corresponding ethyl diester and the cisanhydride 3-oxabicyclo[3.1.0]hexane-2,4-dione was commercially available, and therefore, we chose an approach involving on-resin reduction of the diamide corresponding to the desired 4,4'dimethoxytrityl-protected polyamine. ${ }^{[16]}$

In the present work we focus on incoporating unprecedented structural variations of the polyamine moiety present in both $\mathbf{1}$ and its well-studied close structural analogue, PhTX-343 (2), and examine how these influence the inhibitory effects of the resulting PhTX analogues on a specific subunit, GluA1flop, present in members of the AMPAR subdivision of the ionotropic glutamate receptor family. This subunit is characteristic of a calcium-permeable and polyamine-sensitive subtype of AMPARs, with the flop splice variant (a 38 amino acid region upstream of the fourth transmembrane region) being upregulated in place of the flip splice variant during early development to become dominating in adult CNS. Constraints were introduced in the central region of the polyamine moiety in an attempt to assess the importance of rigidity in this region. This was achieved by solid-phase synthesis incorporating cyclopropane moieties into

\footnotetext{
[a] J. W. Grzeskowiak, Dr. I. R. Mellor School of Life Sciences, University of Nottingham University Park, Nottingham, NG7 2RD, UK E-mail: ian.mellor@nottingham.ac.uk

[b] Dr. H. Franzyk Department of Drug Design and Pharmacology Faculty of Health and Medical Sciences, University of Copenhagen Universitetsparken 2, DK-2100 Copenhagen, Denmark

[c] Dr. Denis B. Tikhonov Sechenov Institute of Evolutionary Physiology and Biochemistry Russian Academy of Sciences St. Petersburg, 194223, Russian Federation
} 
the polyamine chain to give trans- and cis-analogues with 3-4-3 or 4-4-4 (i.e. PhTX-343- or PhTX-444-like) spacing between the nitrogens $(3-6=$ trans-343, trans-444, cis-343, cis-444, respectively; Figure 1). Analogues 2-6 were tested for inhibitory potency against homomeric rat GluA1flop AMPARs expressed in Xenopus oocytes by measurement of their reduction of currents evoked by stimulation with kainic acid (KA; $100 \mu \mathrm{M})$ by using a two-electrode voltage-clamp at a holding potential of $-80 \mathrm{mV}$. Although KA is a weaker agonist of AMPARs it is often used instead of AMPA or L-Glu in these assays to avoid the problem of rapid receptor desensitization.<smiles>CCCC(=O)NC(Cc1ccc(O)cc1)C(=O)NCCCNCCNCCCN</smiles><smiles>CCCC(=O)NC(Cc1ccc(O)cc1)C(=O)NCCCNCC1CC1NCCCN</smiles><smiles>CCCC(=O)NC(Cc1ccc(O)cc1)C(=O)NCCCNCC1CC1</smiles>

Figure 1. Natural (1) and synthetic (2-6) target philanthotoxins (PhTXs)

\section{Results and Discussion}

\section{Solid-phase synthesis of philanthotoxin analogues}

First, cyclopropane-trans-1,2-dicarboxylic acid diethyl ester (7) was converted into the corresponding pentafluorophenyl diester 8 (Scheme 1) via alkaline hydrolysis and subsequent transesterification by using pentafluorophenyl trifluoroacetatepyridine (1:1) in DMF. ${ }^{[15,17]}$ Building blocks 9a and 9b were obtained upon condensation of pentafluorophenyl diester 8 with one equivalent of the appropriate 2-(trimethylsilyl)ethoxycarbonyl (Teoc)-monoprotected diamine. ${ }^{[16 b]}$

In order to minimize cross-linking of the 2-chlorotrityl chloride resin, it was loaded with the appropriate Teocmonoprotected diamine (Scheme 2). A prolonged reaction time of two days enabled a cost-efficient use of these selectively protected diamines as only $10 \%$ excess was required. The resulting resin-bound diamines $\mathbf{1 0 a / 1 0 b}$ were then coupled with building blocks $9 a / 9 b$ to give Teoc-protected diamide intermediates $\mathbf{1 1 a} / \mathbf{1 1} \mathbf{b}$ that were subjected to exchange of the $\mathrm{N}$ protecting group followed by borane reduction to yield the 4,4 'dimethoxytrityl (Dmt)-protected polyamine intermediates 12a/12b. The thus formed secondary amino functionalities were Bocprotected, and then the Dmt group on the terminal primary amine was removed under weakly acidic conditions to give selectively protected resin-bound polyamines $\mathbf{1 3 a} / \mathbf{1 3 b}$. Successive acylation with the activated ester, Fmoc-Tyr('Bu)-OPfp, Fmoc deprotection, acylation with pentafluorophenyl butanoate,${ }^{[18]}$ and cleavage from the linker afforded the crude trans-cyclopropane-containing target philanthotoxins that readily were pufied by reversed-phase preparative HPLC to give PhTXs $\mathbf{3}$ and $\mathbf{4}$ as the tris(TFA) salts.

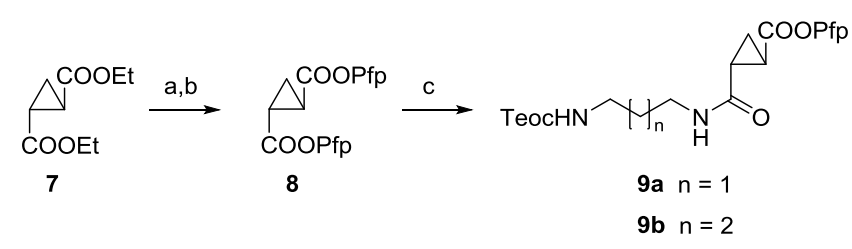

Scheme 1. Reagents and conditions: a) $\mathrm{NaOH}, \mathrm{H}_{2} \mathrm{O}-\mathrm{EtOH}$; b) $\mathrm{CF}_{3} \mathrm{COOPfp}$ (2.5 equiv), pyridine (2.5 equiv), DMF, $19 \mathrm{~h}$; c) $\operatorname{TeocNH}\left(\mathrm{CH}_{2}\right)_{3} \mathrm{NH}_{2}$ or TeocNH $\left(\mathrm{CH}_{2}\right){ }_{4} \mathrm{NH}_{2}$ (1 equiv), DIPEA (2 equiv), $\mathrm{CH}_{2} \mathrm{Cl}_{2}, 19$ h. DIPEA = diisopropylethylamine, $\mathrm{Pfp}=$ pentafluorophenyl, $\mathrm{Teoc}=2$ (trimethylsilyl)ethoxycarbonyl.

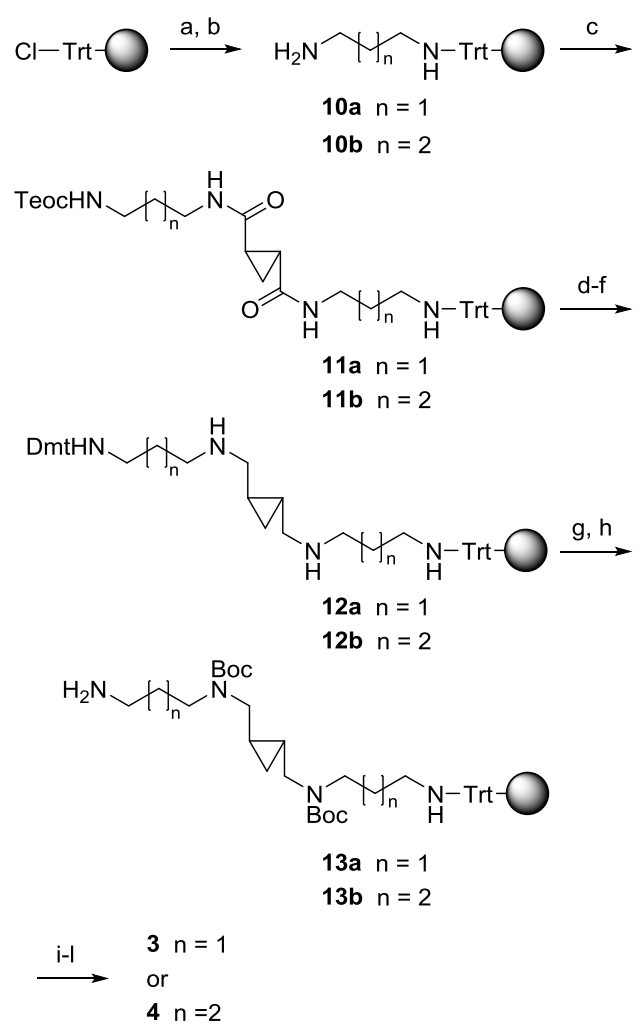

Scheme 2. Reagents and conditions: a) $\mathrm{TeocNH}\left(\mathrm{CH}_{2}\right)_{3} \mathrm{NH}_{2}$ or TeocNH$\left(\mathrm{CH}_{2}\right){ }_{4} \mathrm{NH}_{2}$ (1.1 equiv), DIPEA (5 equiv), $\mathrm{CH}_{2} \mathrm{Cl}_{2}$, 2 days then $\mathrm{CH}_{2} \mathrm{Cl}_{2}-$ $\mathrm{MeOH}-\mathrm{DIPEA}(85: 15: 5), 2 \times 10 \mathrm{~min}$; b) TBAF (3 equiv), DMF, $50{ }^{\circ} \mathrm{C}, 1 \mathrm{~h}$ then room temperature for $3 \mathrm{~h} ; \mathrm{c}$ ) Compound $9 \mathrm{a}$ or $9 \mathrm{~b}$ (2 equiv), HODhBt (1 equiv), DIPEA (2 equiv), DMF, $16 \mathrm{~h}$; d) TBAF (5 equiv), DMF, $55^{\circ} \mathrm{C}, 2 \times 15 \mathrm{~min}$; e) Dmt-Cl (6 equiv), DIPEA ( 6 equiv), $\mathrm{CH}_{2} \mathrm{Cl}_{2}, 3.5 \mathrm{~h}$ then $\mathrm{CH}_{2} \mathrm{Cl}_{2}-\mathrm{MeOH}-\mathrm{DIPEA}$ $(85: 15: 5)$; f) $1 \mathrm{M} \mathrm{BH}_{3} \cdot \mathrm{THF}$ (20 equiv), THF, reflux for $16 \mathrm{~h}$; g) $\mathrm{Boc}_{2} \mathrm{O}$ (10 equiv), DIPEA (10 equiv), $\mathrm{CH}_{2} \mathrm{Cl}_{2}, 16 \mathrm{~h}$; h) $0.1 \mathrm{M}$ chloroacetic acid, $\mathrm{CH}_{2} \mathrm{Cl}_{2}, 4 \times 30 \mathrm{~min}$; i) Fmoc-Tyr(' ${ }^{\mathrm{B} u}$ )-OPfp (3 equiv), HODhBt ( 1 equiv), DIPEA ( 3 equiv), DMF, $2 \times$ $16 \mathrm{~h}$; j) $20 \%$ piperidine-DMF, $2 \times 10 \mathrm{~min}$; k) $\mathrm{C}_{3} \mathrm{H}_{7}$ COOPfp (3 equiv), HODhBt (1 equiv), DIPEA (3 equiv), DMF, $16 \mathrm{~h}$; I) TFA- $\mathrm{CH}_{2} \mathrm{Cl}_{2}(1: 1), 2$ h. TBAF: tetrabutylammmonium fluoride; Dmt-Cl: 4,4'-dimethoxytrityl chloride; HODhBt: 3-hydroxy-1,2,3,-benzotriazin-4(3H)-one. 
SPS of the corresponding cis-cyclopropane-containing PhTXs also started from resin-bound diamines $\mathbf{1 0 a} / \mathbf{1 0 b}$, but in this case these were acylated with the cis-anhydride 3-oxabicyclo[3.1.0]hexane-2,4-dione to give intermediate resins 14a/14b. Elongation with the respective Teoc-monoprotected diamines under $\mathrm{DIC} / \mathrm{HOBt}$ amide coupling conditions followed by removal of the Teoc group furnished the unprotected diamides $15 \mathrm{a} / \mathbf{1 5 b}$. Introduction of the Dmt-protecting group and subsequent borane reduction of the amide fuctionalities gave rise to resins $16 a / 16 b$ that upon Boc-protection and Dmt removal afforded primary amines $\mathbf{1 7 a} / \mathbf{1 7 b}$ that were acylated and cleaved from the resin as described for the trans-analogues to yield PhTXs 5 and $\mathbf{6}$ as the corresponding tris(TFA) salts upon purification.

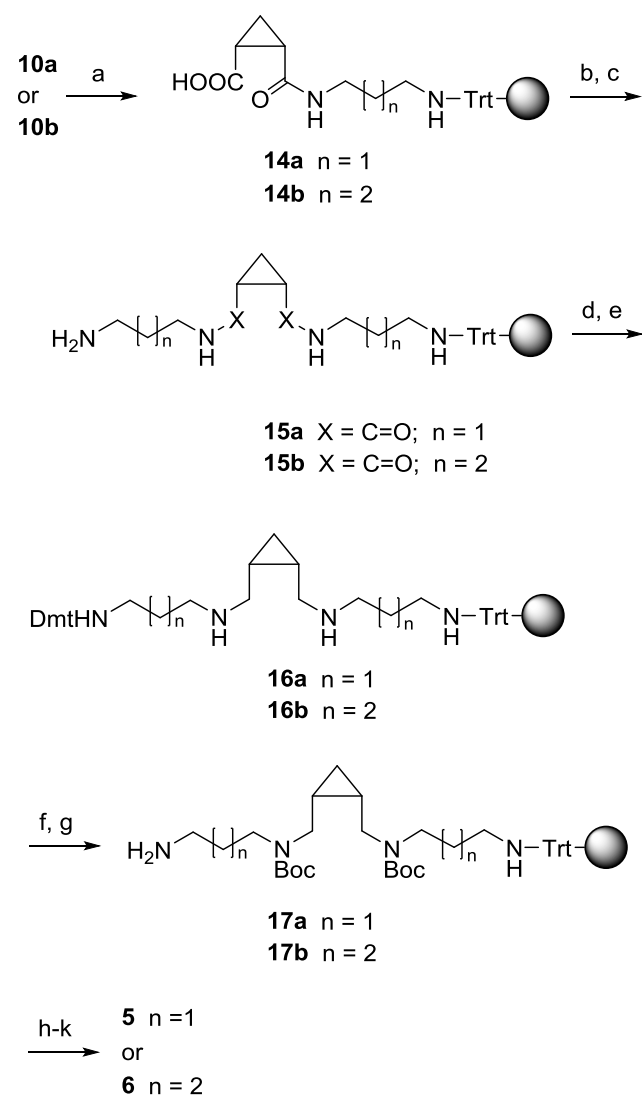

Scheme 3. Reagents and conditions: a) 3-oxabicyclo[3.1.0]hexane-2,4-dione (4 equiv), DIPEA (2 equiv), DMF, $16 \mathrm{~h}$; b) $\operatorname{TeocNH}\left(\mathrm{CH}_{2}\right) \mathrm{mNH}_{2}(\mathrm{~m}=3$ or $4 ; 4$ equiv), HOBt (4 equiv), DIC (4 equiv), DMF, $16 \mathrm{~h}$; c) TBAF (5 equiv), DMF, $55^{\circ} \mathrm{C}, 2 \times$ 15 min; d) Dmt-Cl (6 equiv), DIPEA (6 equiv), $\mathrm{CH}_{2} \mathrm{Cl}_{2}, 3.5 \mathrm{~h}$ then $\mathrm{CH}_{2} \mathrm{Cl}_{2}-$ $\mathrm{MeOH}-\mathrm{DIPEA}(85: 15: 5)$; e) $1 \mathrm{M} \mathrm{BH}_{3}$.THF (20 equiv), THF, reflux for $16 \mathrm{~h} ; \mathrm{f}$ ) $\mathrm{Boc}_{2} \mathrm{O}$ (10 equiv), DIPEA (10 equiv), $\mathrm{CH}_{2} \mathrm{Cl}_{2}, 16 \mathrm{~h} ; \mathrm{g}$ ) $0.1 \mathrm{M}$ chloroacetic acid, $\mathrm{CH}_{2} \mathrm{Cl}_{2}, 4 \times 30 \mathrm{~min}$; h) Fmoc-Tyr('Bu)-OPfp (3 equiv), HODhBt (1 equiv), DIPEA (3 equiv), DMF, $16 \mathrm{~h}$; i) 20\% piperidine-DMF, $2 \times 10 \mathrm{~min}$; j) $\mathrm{C}_{3} \mathrm{H}_{7} \mathrm{COOPfp}(3$ equiv), HODhBt (1 equiv), DIPEA (3 equiv), DMF, 16 h; k) TFA- $\mathrm{CH}_{2} \mathrm{Cl}_{2}$ (1:1), 2 h.

\section{Receptor inhibition by philanthotoxins}

PhTX analogues 2-6 were all able to cause potent inhibition of currents evoked by exposure of oocytes to $100 \mu \mathrm{M}$ KA (Figure 2) with their $\mathrm{IC}_{50}$ values given in Table 1 . The present study is the first to report on PhTX-343 inhibition of homomeric rat GluA1flop channels while previous reports have focused on rat GluA1flip or AMPARs expressed from mRNA extracted from rat brain. We found that the $\mathrm{IC}_{50}$ for GluA1flop inhibition is similar to that for
GluA1flip ${ }^{[12]}$ but is about 10 -fold higher than that observed for KAactivated channels expressed from rat brain mRNA. ${ }^{[4,10]}$ The subunit combination of the latter is not known, but presumably it contains other AMPAR subunits that may be more sensitive to PhTX 2. All of the cyclopropane-containing PhTX analogues (3-6) were significantly more potent inhibitors than 2 , with the transconfigured 3 being the most potent; nearly 30 -fold more so than the corresponding straight-chain PhTX 2.

a)

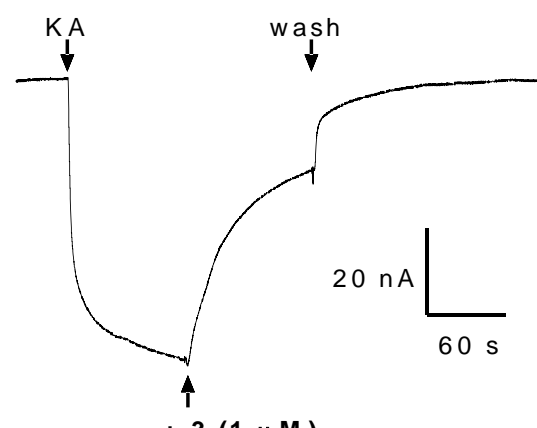

b)

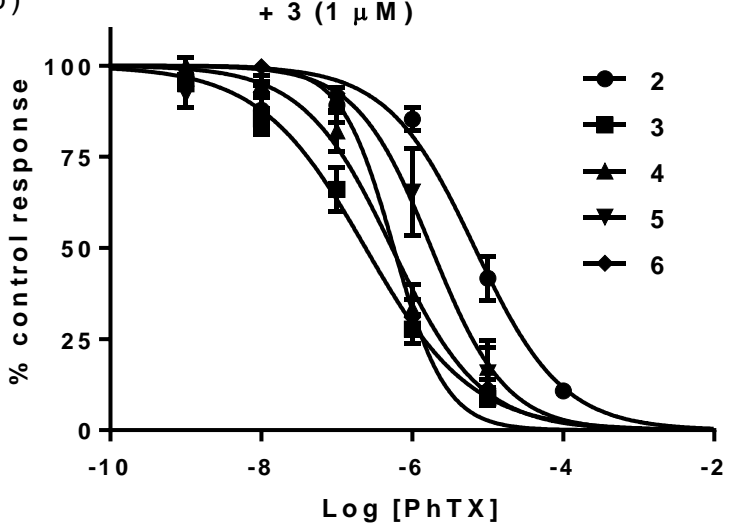

Figure 2. A) Current observed in response to exposure to $100 \mu \mathrm{M} \mathrm{KA}$, and its inhibition following addition of $1 \mu \mathrm{M} \mathrm{PhTX}$ analogue 3 to an oocyte expressing GluA1flop at $\mathrm{V}_{\mathrm{H}}-80 \mathrm{mV}$. B) Concentration-inhibition curves for compounds 2-6 in their inhibition of GluA1flop currents evoked by $100 \mu \mathrm{M} \mathrm{KA}$. Points are mean $\%$ of control response \pm SEM ( $n=4-7$ oocytes). $I_{50}$ values estimated from curve fits (Hill equation) are given in Table 1.

Table 1. $\mathrm{IC}_{50}$ values for inhibition of $100 \mu \mathrm{M}$ KA-evoked GluA1flop currents by PhTXs 2-6 and their relative potencies as compared to PhTX-343 (2).

\begin{tabular}{cccc} 
Compound & $\mathrm{IC}_{50} \pm \operatorname{SEM}(\mu \mathrm{M})$ & $\mathrm{n}$ (oocytes) $^{[\mathrm{a}]}$ & Relative potency $^{[\mathrm{b}]}$ \\
$\mathbf{2}$ & $6.77 \pm 1.41$ & 6 & 1.0 \\
$\mathbf{3}$ & $0.24 \pm 0.04^{[\mathrm{c}]}$ & 6 & 28.2 \\
$\mathbf{4}$ & $0.54 \pm 0.12^{[\mathrm{c}]}$ & 7 & 12.5 \\
$\mathbf{5}$ & $1.79 \pm 0.50^{[\mathrm{d}]}$ & 4 & 3.8 \\
$\mathbf{6}$ & $0.57 \pm 0.06^{[\mathrm{c}]}$ & 6 & 11.9 \\
\hline
\end{tabular}

[a] Number of replicates each representing individual oocytes. [b] Ratio between $\mathrm{IC}_{50}$ values for PhTX 2 and each of the other PhTXs. [c] P $<0.0001$ (significance of difference by an extra sum of squares F-test compared to 2). [d] $\mathrm{P}<0.001$ (significance of difference by an extra sum of squares F-test compared to 2). 


\section{Modelling studies on philanthotoxins}

It is well known that the potency of a philanthotoxin analogue is influenced by changes in the length of the polyamine moiety as well as by the number and distribution of the positively charged amino groups as these factors determine the overall shape and electronic properties of the resulting molecule via intramolecular H-bonding. ${ }^{[3,4,19,20]}$

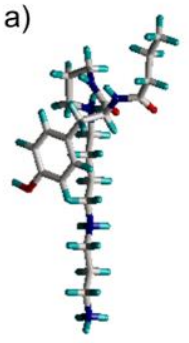

2 "head and tail" c)

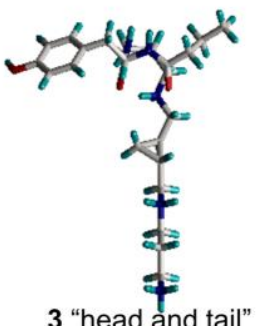

d)

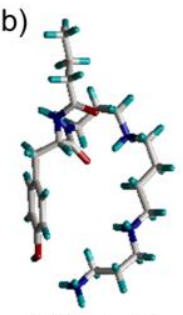

2 "folded"
3 "head and tail"

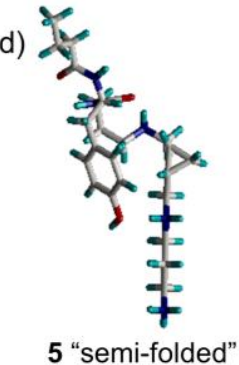

e)

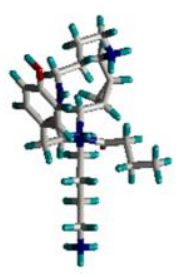

6 "semi-folded" f)

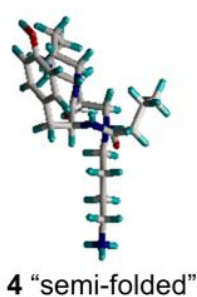

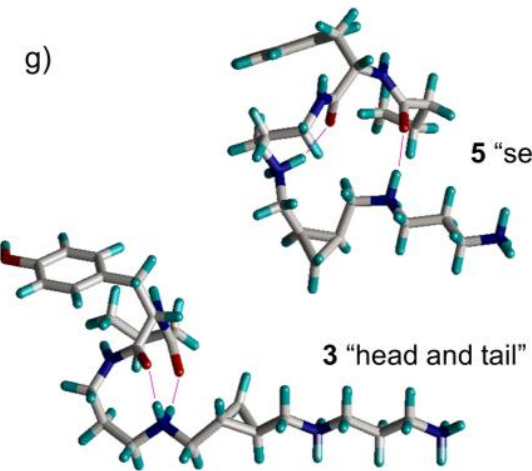

Figure 3. Structures of philanthotoxin analogues 2-6 visualizing the three general conformations that can be adopted: "head and tail" for $2(A)$ and $\mathbf{3}(C)$, "semi-folded" for 4, 5 and $\mathbf{6}(D-F)$ and "folded" for $2(B)$. G) A clearer view of $\mathrm{H}$ bonding (pink lines) between amide oxygens and amine hydrogens in $\mathbf{3}$ for an HT conformation and in $\mathbf{5}$ for a SF conformation.

PhTX analogues can adopt three general low-energy structures, "head and tail" (HT; extended), "semi-folded" (SF) and "folded" (F) (as depicted in Figure 3), depending on whether $\mathrm{H}$ bonding involves the first, second, or third amino group, respectively. The HT structure is believed to be the most active at AMPARs due to previous observations showing that the monocationic analogues are virtually inactive at AMPARs..$^{[4,14]}$ In terms of general shape mono-cationic analogues are "folded" because they do not possess a "tail" at all. Our modelling studies show that for all compounds the vast majority (99.8\%) of low-energy conformations possessed at least one intramolecular $\mathrm{H}$-bond. Ensembles of low-energy conformations obtained for the PhTX analogues studied contained all three types of structures (HT, SF and $\mathrm{F}$ ) within $3 \mathrm{kcal} \mathrm{mol}^{-1}$ from the apparent energy minimum
(0.5-1.0 kcal mol-1). To reveal the conformational preferences of the compounds we compared the relative numbers of conformations belonging to the different types within these ensembles. Compound 2 was found to be distributed as $85 \%$ HT (Figure 3A), 13\% SF and 2\% F (Figure 3B). This was unchanged for $\mathbf{3}$ so the additional hydrocarbon bulk, which in fact becomes part of the head group and relocating the tyrosyl group (Figure 3C), appears to be responsible for the increased potency of 3 . This is reminiscent of analogues where short hydrocarbon chains were introduced to the central section of the polyamine moiety resulting in more potent analogues at insect quisqualate sensitive ionotropic glutamate receptors. ${ }^{[9]}$ The cis-analogue of 3 (i.e compound 5) was less potent as the cis arrangement caused the molecule to adopt a greater proportion of SF structure (44\%) (Figure 3D) at the expense of HT (54\%). The cause of this effect is that in the cis form both amino groups occur at the same side of the bulk and rigid cyclopropane ring. While the trans configuration dictates a rather large distance between amino groups (6.2 $\AA$ in the lowest-energy structure), the cis configuration results in a significantly smaller distance (4.6 $\AA$ ). As a result, the probability that the second amino group is involved in intramolecular $\mathrm{H}$-bonding (and thus the structure is semi-folded) is larger for the cis than the trans configuration (Figure $3 \mathrm{G}$ ).

PhTX analogues 4 and 6 showed intermediate potency between $\mathbf{3}$ and $\mathbf{5}$ since the additional carbon in the chain between the head group and the first amine functionality allowed for more flexibility and hence a higher proportion of SF structures (Figure 3; E-F). The SF structures for these analogues are likely to be more active because of the longer chain between the second and terminal amine groups (giving it a more HT-like structure).

\section{Conclusion}

Introduction of a cyclopropane moiety between the first and second amino groups of PhTX-343 proved beneficial for AMPAR antagonism, but less so for the cis-analogue due to its greater tendency to become semi-folded as inferred by modeling studies. The positive (for trans-analogues) and negative (for cisanalogues) effects of this structural alteration are to some extent obscured by the increased spacing of the amide and the first amine functionality as well as of the second and third amines, such that both PhTX-444 analogues display similar potency.

\section{Experimental Section}

General procedures. Unless otherwise stated, starting materials and solvents were purchased from commercial suppliers $\left(\mathrm{H}-\mathrm{Tyr}\left({ }^{\mathrm{t}} \mathrm{Bu}\right)-\mathrm{OH}\right.$ from Novabiochem, reagents and solvents from Sigma-Aldrich, Fluka, or Lancaster) and used as received. $\mathrm{CH}_{2} \mathrm{Cl}_{2}$ was distilled from $\mathrm{P}_{2} \mathrm{O}_{5}$ and stored over $4 \AA$ molecular sieves. THF was distilled from $\mathrm{Na} /$ benzophenone immediately before use. ${ }^{1} \mathrm{H}$ NMR and ${ }^{13} \mathrm{C} N \mathrm{NMR}$ spectra were recorded at $400.14 \mathrm{MHz}$ and $100.62 \mathrm{MHz}$, respectively, on a Bruker AMX 400 spectrometer, or at $300.06 \mathrm{MHz}$ and $75.45 \mathrm{MHz}$, respectively, on a Varian Mercury Plus spectrometer, using $\mathrm{CDCl}_{3}$ or $\mathrm{CD}_{3} \mathrm{OD}$ as solvents and tetramethylsilane (TMS) as internal standard. Coupling constants ( $J$ values) are given in hertz $(\mathrm{Hz})$, and multiplicities of ${ }^{1} \mathrm{H}$ NMR signals are reported as follows: s, singlet; $d$, doublet; $t$, triplet; q, quartet; $p$, pentet, sx, sextet; m, mulitplet; br, broad. High-resolution mass spectrometry (HRMS) measurements were performed on a Bruker APEX Qe Fourier transform mass spectrometer equipped with a 9.4 tesla superconducting cryomagnet, and an external electrospray ion source (Apollo II source). The spectra were externally calibrated with an arginine cluster in positive 
mode. The samples were dissolved in $\mathrm{MeOH}$, introduced into the electrospray ion source using a syringe pump with a flow of $2 \mu \mathrm{L} / \mathrm{min}$. Solid-phase reactions were performed in Teflon filter vessels on a Scansys PLS $4 \times 6$ Organic Synthesizer equipped with a heating block. Preparative HPLC system consisted of an Agilent 1100 system with 2 preparative pump units, a UV detector, and a Phenomenex Luna $\mathrm{C} 18(2)(5 \mu \mathrm{m})$ column $(25 \times 2.12 \mathrm{~cm})$. Linear elution gradients were composed by mixing solvent $\mathrm{A}\left(\mathrm{MeCN}-\mathrm{H}_{2} \mathrm{O}-\mathrm{TFA}\right.$ 5:95:0.1) and $\mathrm{B}\left(\mathrm{MeCN}-\mathrm{H}_{2} \mathrm{O}-\mathrm{TFA}\right.$ 95:5:0.1) at a flow rate of $20 \mathrm{~mL} / \mathrm{min}$. Analytical HPLC was performed on a Shimadzu system consisting of an SCL10A VP controller, an SIL-10AD VP autosampler, an LC-10AT VP pump, an SPD-M10A VP diode array detector, and a CTO-10AC VP column oven, using a Phenomenex Luna C18(2) $(3 \mu)$ column $(150 \times$ $4.6 \mathrm{~mm}$ ). The HPLC system was controlled by Class VP 6 software; elution was performed with two different solvent systems (total flow of $0.8 \mathrm{~mL} /$ minute). Solvent $\mathrm{A}=\mathrm{MeCN}-\mathrm{H}_{2} \mathrm{O}-\mathrm{TFA}$ 10:90:0.1 and solvent $\mathrm{B}=\mathrm{MeCN}-\mathrm{H}_{2} \mathrm{O}-\mathrm{TFA} 90: 10: 0.1 ; \mathrm{t}=0-5 \mathrm{~min} 0 \% \mathrm{~B}, \mathrm{t}=5-30 \min 0-40 \%$ $B, t=30-35$ min $40-100 \%$ B). The purities of target compounds 3-6 were determined (from UV absorption integration at $\lambda=215 \mathrm{~nm}$ ) and were within the ranges $97-99 \%$.

Dipentafluorophenyl Cyclopropane-trans-1,2-dicarboxylate (8): Diethyl trans-1,2-cyclopropanedicarboxylate $(7,5.15 \mathrm{~g}, 27.7 \mathrm{mmol})$ was subjected to hydrolysis with $\mathrm{NaOH}(5.16 \mathrm{~g}, 4.66 \times 27.7 \mathrm{mmol})$ in $\mathrm{H}_{2} \mathrm{O}-\mathrm{EtOH}(2: 1,75 \mathrm{~mL})$ for $4 \mathrm{~h}$ at room temperature. The reaction mixture was diluted with $\mathrm{H}_{2} \mathrm{O}(200 \mathrm{~mL})$, and then washed with $\mathrm{Et}_{2} \mathrm{O}$ $(100 \mathrm{~mL})$, which was extracted back with $\mathrm{H}_{2} \mathrm{O}(50 \mathrm{~mL})$. The combined aqueous phases were concentrated to dryness in vacuo. The residue was partially dissolved in EtOAc $(100 \mathrm{~mL})$, which then was filtered through a layer of $\mathrm{Na}_{2} \mathrm{SO}_{4}$. The filtrate was evaporated to give the crude diacid $(2.98 \mathrm{~g}, 83 \%)$. The diacid $(1.40 \mathrm{~g}, 10.8 \mathrm{mmol})$ was treated with $\mathrm{CF}_{3} \mathrm{COOPfp}(4.64 \mathrm{~mL}, 2.5 \times 10.8 \mathrm{mmol})$ and pyridine $(2.18 \mathrm{~mL}, 2.5 \times 10.8 \mathrm{mmol})$ in dry DMF $(15 \mathrm{~mL})$ for $19 \mathrm{~h}$ under $\mathrm{N}_{2}$. The reaction mixture was diluted with EtOAc $(250 \mathrm{~mL})$, and then extracted successively with $0.1 \mathrm{M} \mathrm{HCl}(3 \times 150 \mathrm{~mL})$, saturated aqueous $\mathrm{NaHCO}_{3}(3 \times 150 \mathrm{~mL})$, and brine $(150 \mathrm{~mL})$. Upon drying $\left(\mathrm{Na}_{2} \mathrm{SO}_{4}\right)$ the solvent was removed to give $8(4.86 \mathrm{~g}, 98 \%) .{ }^{1} \mathrm{H}$ NMR $\left(300 \mathrm{MHz}, \mathrm{CDCl}_{3}\right): \delta=1.81$ (t, $J=7.5 \mathrm{~Hz}, 2 \mathrm{H}$ ), 2.65 (t, $J=7.5 \mathrm{~Hz}$, $2 \mathrm{H}) ;{ }^{13} \mathrm{C}$ NMR $\left(75 \mathrm{MHz}, \mathrm{CDCl}_{3}\right): \delta=17.6,22.3(2 \mathrm{C}), 124.5,137.7$ (2C), 139.7, $141.0(2 \mathrm{C}), 167.0$. Anal. calcd for $\mathrm{C}_{17} \mathrm{H}_{4} \mathrm{~F}_{10} \mathrm{O}_{4}: \mathrm{C} 44.18, \mathrm{H}$ 0.87, found: C 44.31, H 0.58 .

Protected Monoamides (9a/9b) from Dipentafluorophenyl Cyclopropane-trans-1,2-carboxylate: The diPfp ester (1.78 g, 3.85 mmol) was dissolved in dry $\mathrm{CH}_{2} \mathrm{Cl}_{2}(25 \mathrm{~mL})$, and then the appropriate Teoc-monoprotected diamine $(3.85 \mathrm{mmol})$ and DIPEA $(1.34 \mathrm{~mL}, 2 \times$ $3.85 \mathrm{mmol})$ in dry $\mathrm{CH}_{2} \mathrm{Cl}_{2}(10 \mathrm{~mL})$, were added. After $19 \mathrm{~h}$, the reaction mixture was diluted with EtOAc $(150 \mathrm{~mL})$, and then washed with $0.1 \mathrm{M} \mathrm{HCl}-$ brine $(3: 1,3 \times 100 \mathrm{~mL}), \mathrm{H}_{2} \mathrm{O}(100 \mathrm{ml})$, satd $\mathrm{NaHCO}_{3}-$ brine $(3: 1,3 \times 100 \mathrm{~mL})$, and brine $(75 \mathrm{~mL})$. The organic layer was dried $\left(\mathrm{Na}_{2} \mathrm{SO}_{4}\right)$ and concd. The residue was dissolved in $\mathrm{CH}_{2} \mathrm{Cl}_{2}(15$ $\mathrm{mL})$ and loaded onto a VLC column $(5.5 \times 6 \mathrm{~cm})$, which was eluted with hexane and then hexane- $\mathrm{Me}_{2} \mathrm{CO} 20: 1$ to $4: 1$. This afforded 9a $(1.24 \mathrm{~g}, 65 \%)$ or $9 \mathbf{b}(1.10 \mathrm{~g}, 56 \%) .9 \mathrm{a}:{ }^{1} \mathrm{H}$ NMR $\left(300 \mathrm{MHz}, \mathrm{CDCl}_{3}\right): \delta=$ $0.03(\mathrm{~s}, 9 \mathrm{H}), 0.97$ (brt $J=8.5 \mathrm{~Hz}, 2 \mathrm{H}$ ), 1.52 (ddd, $J=9.2,5.5,4.1 \mathrm{~Hz}$ $1 \mathrm{H}$ ), 1.61-1.71 (br m, 3H), 2.20 (ddd, $J=9.2,6.0,3.9 \mathrm{~Hz}, 1 \mathrm{H}$ ), 2.48 (ddd, $J=9.1,5.5,3.9 \mathrm{~Hz}, 1 \mathrm{H}), 3.35(\mathrm{~m}, 2 \mathrm{H}), 3.24(\mathrm{~m}, 2 \mathrm{H}), 4.14(\mathrm{br} \mathrm{t}, J$ $=8.5 \mathrm{~Hz}, 2 \mathrm{H}), 5.05(\mathrm{br} \mathrm{s}, 1 \mathrm{H}), 6.84(\mathrm{br} \mathrm{s}, 1 \mathrm{H}) \mathrm{ppm} ;{ }^{13} \mathrm{C} \mathrm{NMR}(75 \mathrm{MHz}$, $\left.\mathrm{CDCl}_{3}\right): \delta=-1.4,16.2,17.8,20.3,25.6,30.1,36.3,37.5,62.3,157.5$, 168.7, $169.1 \mathrm{ppm}$. HRMS $\mathrm{m} / \mathrm{z}[\mathrm{M}+\mathrm{Na}]^{+}$calcd for $\mathrm{C}_{20} \mathrm{H}_{25} \mathrm{~F}_{5} \mathrm{~N}_{2} \mathrm{NaO}_{5} \mathrm{Si}$ : 519.13451, found 519.13431. 9b: ${ }^{1} \mathrm{H}$ NMR $\left(300 \mathrm{MHz}, \mathrm{CDCl}_{3}\right): \delta=$ 0.02 (s, 9H), 0.96 (br t, $J=8.5 \mathrm{~Hz}, 2 \mathrm{H}), 1.51$ (ddd, $J=9.0,5.5,3.9 \mathrm{~Hz}$, $1 \mathrm{H}), 1.56(\mathrm{~m}, 4 \mathrm{H}), 1.77$ (ddd, $J=9.0,6.1,3.9 \mathrm{~Hz}, 1 \mathrm{H}), 2.16$ (ddd, $J=$ $9.0,6.1,3.9 \mathrm{~Hz}, 1 \mathrm{H}$ ), 2.47 (ddd, $J=9.0,5.5,3.9 \mathrm{~Hz}, 1 \mathrm{H}), 3.32(\mathrm{~m}, 2 \mathrm{H})$, $3.29(\mathrm{~m}, 2 \mathrm{H}), 4.13(\mathrm{br} \mathrm{t}, J=8.5 \mathrm{~Hz}, 2 \mathrm{H}), 4.79(\mathrm{br} \mathrm{s}, 1 \mathrm{H}), 6.43(\mathrm{br} \mathrm{s}$, 1H) ppm; ${ }^{13} \mathrm{C}$ NMR $\left(75 \mathrm{MHz}, \mathrm{CDCl}_{3}\right): \delta=-1.4,16.1,17.9,20.3,25.5$, $26.5,27.8,39.7,40.4,63.1,156.9,168.7,168.9 \mathrm{ppm}$. HRMS $\mathrm{m} / \mathrm{z}$ $[\mathrm{M}+\mathrm{Na}]^{+}$calcd for $\mathrm{C}_{21} \mathrm{H}_{27} \mathrm{~F}_{5} \mathrm{~N}_{2} \mathrm{NaO}_{5} \mathrm{Si}: 533.15016$, found 533.14995.

Preparation of resin-bound diamines 10a/10b: $\quad \mathrm{N}^{1}-[2$ Trimethylsilyl)ethoxycarbonyl)]-1,3-propanediamine was prepared (in
$74 \%$ yield) as earlier reported for $\mathrm{N}^{1}$-[2-trimethylsilyl)ethoxycarbonyl)]1,4-butanediamine. ${ }^{[16 \mathrm{~b}]}{ }^{1} \mathrm{H} \mathrm{NMR}\left(300 \mathrm{MHz}, \mathrm{CDCl}_{3}\right): \delta=0.02(\mathrm{~s}, 9 \mathrm{H})$, $0.96(\mathrm{t}, J=8.5 \mathrm{~Hz}, 2 \mathrm{H}), 1.67(\mathrm{p}, J=6.6 \mathrm{~Hz}, 2 \mathrm{H}), 2.82(\mathrm{t}, J=6.6 \mathrm{~Hz}$, 2H), $3.26(\mathrm{~m}, 2 \mathrm{H}), 4.12$ (br t, $J=8.5 \mathrm{~Hz}, 2 \mathrm{H}) \mathrm{ppm} ;{ }^{13} \mathrm{C} \mathrm{NMR}(75 \mathrm{MHz}$, $\left.\mathrm{CDCl}_{3}\right): \delta=-1.2,17.9,38.8,39.4,62.9,157.0 \mathrm{ppm}$. Trityl chloride resin $\left(1.89 \mathrm{~g}, \sim 2.2 \mathrm{mmol} / \mathrm{g}\right.$ ) prewashed with $10 \%$ DIPEA- $\mathrm{CH}_{2} \mathrm{Cl}_{2}$ was added to a gently stirred solution of Teoc-monoprotected diamine (1.1 $\times 4.16 \mathrm{mmol})$ and DIPEA $(3.6 \mathrm{~mL}, 5 \times 4.16 \mathrm{mmol})$ in dry $\mathrm{CH}_{2} \mathrm{Cl}_{2}(20$ $\mathrm{mL}$ ). After 2 days, the resin was transferred to a $20 \mathrm{~mL}$ syringe, and then washed with $\mathrm{CH}_{2} \mathrm{Cl}_{2}(2 \times 15 \mathrm{~mL})$ and subsequently end-capped with $\mathrm{CH}_{2} \mathrm{Cl}_{2}-\mathrm{MeOH}$-DIPEA (80:15:5, $\left.15 \mathrm{~mL}, 2 \times 10 \mathrm{~min}\right)$. The resin was then washed with $\mathrm{CH}_{2} \mathrm{Cl}_{2}, \mathrm{MeOH}$, dry $\mathrm{CH}_{2} \mathrm{Cl}_{2}$ (each $3 \times$ ), dried overnight (to give $2.52 \mathrm{~g}$ and $2.57 \mathrm{~g}$, respectively of resin-bound Teoc-protected 1,3-propanediamine and 1,4-butanediamine, repectively). Then the Teoc groups were removed by treatment with TBAF (3 equiv) in dry DMF ( $45 \mathrm{~mL}$; in a round-bottomed flask) at 50 ${ }^{\circ} \mathrm{C}$ for $1 \mathrm{~h}$ and then at room temperature for $3 \mathrm{~h}$. The resins were then washed with $\mathrm{CH}_{2} \mathrm{Cl}_{2}, \mathrm{MeOH}$, dry $\mathrm{CH}_{2} \mathrm{Cl}_{2}$ (each $3 \times$ ), dried overnight (to give $\sim 2.0 \mathrm{~g}, \mathbf{1 0 a} / \mathbf{1 0 b})$. The loadings were determined to be $\sim 1.8$ $\mathrm{mmol} / \mathrm{g}$ based on the mass gain and coupling with Fmoc-Gly-OH.

SPS of Protected trans-Cyclopropane PhTX-Analogues: Resinbound diamines (10a/10b, $0.44 \mathrm{mmol})$ were swelled in dry DMF for 30 $\mathrm{min}$. The solvent was removed by suction, and the resin was treated with a cyclopropane building block (9a or $\mathbf{9 b}, 2$ equiv), HODhBt (1 equiv) and DIPEA (2 equiv) in dry DMF (10 $\mathrm{mL} / \mathrm{mmol}$ resin). The mixture was shaken for $16 \mathrm{~h}$ at room temperature. The resin was drained and then washed with DMF, $\mathrm{MeOH}, \mathrm{CH}_{2} \mathrm{Cl}_{2}$ and DMF $(3 \times 12$ $\mathrm{mL} / \mathrm{mmol}$ resin with each solvent). The Teoc group was removed by treatment with TBAF (5 equiv) in DMF $\left(7.5 \mathrm{~mL} / \mathrm{mmol}\right.$ resin) at $55^{\circ} \mathrm{C}$ for $15 \mathrm{~min}$. Upon draining and wash with DMF, this deprotection step was repeated. The resin was drained and then washed with DMF, $\mathrm{MeOH}$, and $\mathrm{CH}_{2} \mathrm{Cl}_{2}(3 \times)$. Dmt- $\mathrm{Cl}$ (6 equiv) in dry $\mathrm{CH}_{2} \mathrm{Cl}_{2}(9 \mathrm{~mL} / \mathrm{mmol}$ resin) and DIPEA (6 equiv) were added to the resin. After $3.5 \mathrm{~h}$, the resin was drained and washed with $\mathrm{CH}_{2} \mathrm{Cl}_{2}, \mathrm{CH}_{2} \mathrm{Cl}_{2}-\mathrm{MeOH}$-DIPEA (80:15:5), DMF, $\mathrm{CH}_{2} \mathrm{Cl}_{2}$, and THF (each $3 \times$ ). The resin was transferred to a $25 \mathrm{~mL}$ flask with a minimum of THF, and then $1 \mathrm{M}$ $\mathrm{BH}_{3} \cdot \mathrm{THF}$ in THF (20 equiv) was added. The flask was heated to reflux under $\mathrm{N}_{2}$ in an oil bath $\left(70{ }^{\circ} \mathrm{C}\right)$ for $16 \mathrm{~h}$. The resin was transferred back to a teflon reactor using THF. Upon draining, the resin was washed with $\mathrm{MeOH}(3 \times)$. Then the resin was treated with piperidine $\left(9 \mathrm{~mL} / \mathrm{mmol}\right.$ resin) at $60^{\circ} \mathrm{C}$ for $1.5 \mathrm{~h}$. After washing with $\mathrm{MeOH}(12$ $\mathrm{mL} / \mathrm{mmol}$ ), this decomplexation procedure was repeated twice. The resin was treated with $\mathrm{Boc}_{2} \mathrm{O}$ (10 equiv) and DIPEA (10 equiv) in dry $\mathrm{CH}_{2} \mathrm{Cl}_{2}(6 \mathrm{~mL} / \mathrm{mmol}$ resin) for $16 \mathrm{~h}$ followed by draining and wash with DMF, $\mathrm{MeOH}, \mathrm{DMF}$, and $\mathrm{CH}_{2} \mathrm{Cl}_{2}$ (each $3 \times$ ). Dmt deprotection with $0.1 \mathrm{M} \mathrm{ClAcOH}$ in $\mathrm{CH}_{2} \mathrm{Cl}_{2}(14 \mathrm{~mL} / \mathrm{mmol}$ resin) for 30 min followed by wash with $\mathrm{CH}_{2} \mathrm{Cl}_{2}$ was repeated three times. The resin was drained and washed with DMF, $\mathrm{MeOH}, \mathrm{CH}_{2} \mathrm{Cl}_{2}$, and dry DMF (each $3 \times$ ). The resulting resin was coupled with Fmoc-Tyr( $\left.{ }^{(} \mathrm{Bu}\right)-\mathrm{OPfp}$ (3 equiv), HODhBt (1 equiv), and DIPEA ( 3 equiv) in dry DMF $(7 \mathrm{~mL} / \mathrm{mmol}$ resin) for $16 \mathrm{~h}$. Upon draining, the resin was washed with DMF, $\mathrm{MeOH}, \mathrm{CH}_{2} \mathrm{Cl}_{2}$, and dry DMF (each $3 \times$ ). Coupling with Fmoc$\operatorname{Tyr}\left({ }^{(} \mathrm{Bu}\right)$-OPfp was repeated (due to a positive Kaiser test) using DMF- $\mathrm{CH}_{2} \mathrm{Cl}_{2} \quad(3: 1)$ as solvent. Fmoc deprotection with $20 \%$ piperidine-DMF (11 $\mathrm{mL} / \mathrm{mmol}$ resin) for $10 \mathrm{~min}$ was repeated after a DMF wash. Upon draining, the resin was washed with DMF, $\mathrm{MeOH}$, $\mathrm{CH}_{2} \mathrm{Cl}_{2}$, and dry DMF (each $\left.3 \times\right)$. The resulting resin was treated with pentafluorophenyl butanoate (3 equiv), HODhBt (1 equiv), and DIPEA ( 3 equiv) in dry DMF ( $8 \mathrm{~mL} / \mathrm{mmol}$ resin) for $16 \mathrm{~h}$. Upon draining, the resin was washed with $\mathrm{DMF}, \mathrm{MeOH}$, and $\mathrm{CH}_{2} \mathrm{Cl}_{2}$ (each $3 \times$ ). Cleavage of the product from the resin was performed with TFA$\mathrm{CH}_{2} \mathrm{Cl}_{2}(1: 1,9 \mathrm{~mL} / \mathrm{mmol}$ resin) for $2 \mathrm{~h}$. The filtrate was collected by suction, and the resin eluted further with $\mathrm{CH}_{2} \mathrm{Cl}_{2}$ and $\mathrm{MeOH}$ (each $2 \times$ $9 \mathrm{~mL} / \mathrm{mmol}$ resin). The combined filtrates were concentrated, and the residue purified by preparative HPLC (>95\% purity): $3(46 \mathrm{mg})$ and 4 $(115 \mathrm{mg})$. 3: ${ }^{1} \mathrm{H}$ NMR $\left(300 \mathrm{MHz}\right.$, methanol- $\left.\mathrm{d}_{4}\right): \delta=0.85$ (br t, $J=6.6$ $\mathrm{Hz}, 2 \mathrm{H}$ ), 0.87 (t, $J=7.4 \mathrm{~Hz}, 3 \mathrm{H}), 1.22(\mathrm{~m}, 2 \mathrm{H}), 1.56(\mathrm{sx}, J=7.4 \mathrm{~Hz}$ 2H), 1.81 (br p, $J=6.5 \mathrm{~Hz}, 2 \mathrm{H}), 2.10(\mathrm{~m}, 2 \mathrm{H}), 2.18(\mathrm{t}, J=7.4 \mathrm{~Hz}, 2 \mathrm{H})$, 2.82-3.30 (br m, 14H), 4.49*/4.50 (t, $J=7.7 \mathrm{~Hz}, 1 \mathrm{H}), 6.71$ (d, $J=8.3$ $\mathrm{Hz}, 2 \mathrm{H}), 7.06$ (d, $J=8.3 \mathrm{~Hz}, 2 \mathrm{H}) ;{ }^{13} \mathrm{C}$ NMR $\left(75 \mathrm{MHz}\right.$, methanol- $\left.\mathrm{d}_{4}\right): \delta$ $=10.8,14.0,15.5^{* * *}, 15.6^{*}, 20.3,25.4,27.5^{*} / 27.4^{*}, 36.7,37.8,38.0$, 
38.6, 45.6, 46.0*/45.9* 52.1, 52.2, 57.1, 116.2, 117.6, 128.7, 131.1, $157.2,162.1,175.1^{*} / 175.0^{*}, 176.0$; "signals with half intensity (splitting due to presence of diastereomers); "two distinct close signals. HRMS $\mathrm{m} / \mathrm{z}[\mathrm{M}+\mathrm{H}]^{+}$calcd for $\mathrm{C}_{24} \mathrm{H}_{42} \mathrm{~N}_{5} \mathrm{O}_{3}: 448.32822$, found 448.32830. 4: ${ }^{1} \mathrm{H}$ NMR $\left(300 \mathrm{MHz}\right.$, methanol- $\left.\mathrm{d}_{4}\right): \delta=0.84(\mathrm{t}, \mathrm{J}=7.4 \mathrm{~Hz}, 3 \mathrm{H}), 0.84$ (obsc. $2 \mathrm{H}), 1.22(\mathrm{~m}, 2 \mathrm{H}), 1.53(\mathrm{sx}, J=7.4 \mathrm{~Hz}, 2 \mathrm{H}), 1.42-1.66(\mathrm{br} \mathrm{m}, 4 \mathrm{H})$ 1.67-1.85 (br m, 4H), 2.16 (t, $J=7.4 \mathrm{~Hz}, 2 \mathrm{H}$ ), 2.79 (dd, $J=13.7$ and $8.5 \mathrm{~Hz}, 1 \mathrm{H}$ ), 2.87-3.15 (br m, 13H), 4.52 (dd, $J=8.5$ and $6.9 \mathrm{~Hz}, 1 \mathrm{H}$ ) $6.69(\mathrm{~d}, J=8.5 \mathrm{~Hz}, 2 \mathrm{H}), 7.04(\mathrm{~d}, J=8.5 \mathrm{~Hz}, 2 \mathrm{H}) \mathrm{ppm} ;{ }^{13} \mathrm{C}$ NMR $(75$ $\mathrm{MHz}$, methanol- $\left.\mathrm{d}_{4}\right): \delta=11.0,14.0,15.4(2 \mathrm{C}), 20.3,24.2,24.3,25.6$, 27.3, 38.2, 38.7, 39.3, 40.0, 47.9, 48.2, 51.8, 52.0, 56.8, 116.1, 117.7, $128.9,131.1,157.1,162.4,173.9,175.8$. HRMS $\mathrm{m} / z[\mathrm{M}+\mathrm{H}]^{+}$calcd for $\mathrm{C}_{26} \mathrm{H}_{46} \mathrm{~N}_{5} \mathrm{O}_{3}: 476.35952$, found 476.35956 .

SPS of Protected cis-Cyclopropane PhTX-Analogues: Resinbound diamines (10a/10b, $0.55 \mathrm{mmol})$ were swelled in dry DMF for 30 min. The solvent was removed by suction, and a solution of 3 oxabiclo[3.1.0] hexane-2,4-dione (4 equiv) and DIPEA (2 equiv) in dry DMF $(7 \mathrm{~mL} / \mathrm{mmol}$ resin) was added to the resin. After $16 \mathrm{~h}$, the resin was drained and washed with DMF, $\mathrm{MeOH}, \mathrm{DMF}$, and dry $\mathrm{CH}_{2} \mathrm{Cl}_{2}$ (each $3 \times 12 \mathrm{~mL} / \mathrm{mmol}$ resin). Then the resin was treated with Teocmonoprotected diamine (4 equiv), HOBt (4 equiv), and DIC (3 equiv) in dry DMF ( $8 \mathrm{~mL} / \mathrm{mmol}$ resin) for $16 \mathrm{~h}$. The resin was drained and washed with DMF, $\mathrm{MeOH}, \mathrm{DMF}$, and dry $\mathrm{CH}_{2} \mathrm{Cl}_{2}$ (each $3 \times$ ). Successive Teoc deprotection, introduction of Dmt protecting groups, borane reduction/decomplexation, and Boc protection were performed as described above for trans-analogues. Upon draining and wash with DMF, MeOH, DMF, and $\mathrm{CH}_{2} \mathrm{Cl}_{2}$ (each $3 \times$ ), Dmt groups were removed with $0.1 \mathrm{M} \mathrm{ClAcOH}$ in $\mathrm{CH}_{2} \mathrm{Cl}_{2}(11 \mathrm{~mL} / \mathrm{mmol}$ resin, $4 \times 30 \mathrm{~min})$. The resin was drained and washed with DMF, $\mathrm{MeOH}, \mathrm{CH}_{2} \mathrm{Cl}_{2}$, and dry DMF (each $3 \times$ ). The resulting resin was elongated with the Tyr residue, and subsequently terminated by introduction of the $\mathrm{N}$-butyryl group as described above (using single couplings for $16 \mathrm{~h}$ ). Cleavage of the product from the resin was performed with TFA- $\mathrm{CH}_{2} \mathrm{Cl}_{2}(1: 1,7$ $\mathrm{mL} / \mathrm{mmol}$ resin) for $2 \mathrm{~h}$. The crude products were purified by preparative HPLC (>95\% purity): $5(220 \mathrm{mg})$ and $6(64 \mathrm{mg}) .5:{ }^{1} \mathrm{H}$ NMR $\left(300 \mathrm{MHz}\right.$, methanol- $\left.\mathrm{d}_{4}\right): \delta=0.56^{*} / 0.58^{*}(\mathrm{q}, J=5.8 \mathrm{~Hz}, 1 \mathrm{H})$ $0.85^{*} / 0.86^{*}(\mathrm{t}, J=7.5 \mathrm{~Hz}, 3 \mathrm{H}), 1.11(\mathrm{~m}, 1 \mathrm{H}), 1.39(\mathrm{~m}, 2 \mathrm{H}), 1.54^{*} / 1.56^{*}$ (sx, $J=7.5 \mathrm{~Hz}, 2 \mathrm{H}), 1.82(\mathrm{p}, J=6.6 \mathrm{~Hz}, 2 \mathrm{H}), 2.15-2.22(\mathrm{br} \mathrm{m}, 4 \mathrm{H})$ 2.79-3.30 (br m, 14H), 4.39*/4.40* (t, $J=7.7 \mathrm{~Hz}, 1 \mathrm{H}), 6.72(\mathrm{~d}, J=8.4$ $\mathrm{Hz}, 2 \mathrm{H}), 7.06^{*} / 7.07^{*}(\mathrm{~d}, \mathrm{~J}=8.4 \mathrm{~Hz}, 2 \mathrm{H}) \mathrm{ppm} ;{ }^{13} \mathrm{C}$ NMR $(75 \mathrm{MHz}$ methanol-d 4 ): $\delta=10.2^{*} / 10.5^{*}, 13.8^{* * *} / 13.9^{*}, 14.0^{* *}, 20.3,25.4,27.4$ $36.7^{*} / 36.8^{*}, 37.8,38.0^{*, * *}, 38.6^{*, * *}, 45.7^{*, *} / 45.8^{*, * *}, 46.0^{*, * *}, 48.4$ (2C), $57.0^{*} / 57.2^{*}, 116.1^{*} / 116.2^{*}, 118.0,128.8,131.1^{*} / 131.2^{*}, 157.2^{* * *}, 162.9$ $174.9^{*} / 175.1^{*}, 176.0^{*, *} \mathrm{ppm}$; "signals with half intensity (splitting due to presence of diastereomers); "two distinct close signals. HRMS $\mathrm{m} / \mathrm{z}$ $[\mathrm{M}+\mathrm{H}]^{+}$calcd for $\mathrm{C}_{24} \mathrm{H}_{42} \mathrm{~N}_{5} \mathrm{O}_{3}: 448.32822$, found 448.32802. 6: ${ }^{1} \mathrm{H}$ NMR (300 MHz, methanol-d $\left.\mathrm{d}_{4}\right): \delta=0.60(\mathrm{q}, J=5.5 \mathrm{~Hz}, 1 \mathrm{H}), 0.85(\mathrm{t}, J=$ $7.4 \mathrm{~Hz}, 3 \mathrm{H}), 1.12(\mathrm{~m}, 1 \mathrm{H}), 1.39(\mathrm{~m}, 2 \mathrm{H}), 1.45-1.68(\mathrm{br} \mathrm{m}, 4 \mathrm{H}), 1.54$ (sx, $J=7.4 \mathrm{~Hz}, 2 \mathrm{H}), 1.77(\mathrm{~m}, 4 \mathrm{H}), 2.16$ (t, $J=7.4 \mathrm{~Hz}, 2 \mathrm{H}$ ), 2.80 (dd, $J$ $=13.7$ and $8.5 \mathrm{~Hz}, 1 \mathrm{H}), 2.89-3.38(\mathrm{br} \mathrm{m}, 13 \mathrm{H}), 4.42(\mathrm{dd}, J=8.5$ and $6.9 \mathrm{~Hz}, 1 \mathrm{H}), 6.70(\mathrm{~d}, J=8.5 \mathrm{~Hz}, 2 \mathrm{H}), 7.05(\mathrm{~d}, J=8.5 \mathrm{~Hz}, 2 \mathrm{H}) \mathrm{ppm}$ ${ }^{13} \mathrm{C}$ NMR $\left(75 \mathrm{MHz}\right.$, methanol- $\left.\mathrm{d}_{4}\right): \delta=10.6,13.8^{* *}, 14.0,20.3,24.2$, 24.3, 25.6, 27.3, 38.2, 38.7, 39.3, 40.0, 48.0, 48.2, 48.3 (2C), 56.9, $116.1,118.0,128.9,131.1,157.1,162.7,173.9,175.9$ ppm; "two distinct close signals. HRMS $\mathrm{m} / \mathrm{z}[\mathrm{M}+\mathrm{H}]^{+}$calcd for $\mathrm{C}_{26} \mathrm{H}_{46} \mathrm{~N}_{5} \mathrm{O}_{3}$ : 476.35952, found 476.35936 .

AMPAR Inhibition Assay. A two-electrode voltage-clamp (TEVC) was used to record responses to $100 \mu \mathrm{M} \mathrm{KA}$ of Xenopus laevis oocytes expressing AMPARs containing GluA1flop subunits. $X$. laevis oocytes were injected with cRNA encoding GluA1flop and incubated at $18{ }^{\circ} \mathrm{C}$ for at least three days. Single oocytes were transferred to a perfusion bath and continuously washed with saline containing $96 \mathrm{mM}$ $\mathrm{NaCl}, 2 \mathrm{mM} \mathrm{KCl}, 2 \mathrm{mM} \mathrm{CaCl}_{2}, 1 \mathrm{mM} \mathrm{MgCl}$ and $5 \mathrm{mM} \mathrm{HEPES}(\mathrm{pH}$ adjusted 7.5 with $\mathrm{NaOH}$ ). Microelectrodes were pulled from borosilicate glass capillaries (GC150TF-10, Harvard Apparatus) using a Sutter P-97 programmable puller and had resistances of $\sim 0.5 \mathrm{M} \Omega$ when filled with $3.0 \mathrm{M} \mathrm{KCl}$. The oocytes were voltage clamped at -80 $\mathrm{mV}$ using an Axoclamp 2B (Axon Instruments) and output currents were transferred to a $\mathrm{PC}$ via a $\mathrm{NI} \mathrm{PCl-6221} \mathrm{A-D} \mathrm{interface} \mathrm{(National}$
Instruments, UK) and WinEDR software (Dr John Dempster, University of Strathclyde, UK). Responses of AMPAR were elicited by perfusion of $100 \mu \mathrm{M} \mathrm{KA}$ until a stable control current was obtained (60-90 s) then 2-6 were co-applied until a new plateau current was obtained (60-90 s). This was repeated for 2-6 concentrations in the range $10^{-9}-10^{-5} \mathrm{M}\left(+10^{-4} \mathrm{M}\right.$ for 2). Percent of control response was plotted against concentration of PhTX analogue and fit with a Hill equation to estimate the $\mathrm{IC}_{50}$. Analysis was performed using GraphPad Prism 6.

Molecular Modelling. Calculations were performed by using ZMM (ZMM Software, Inc., Flamborough, Ontario, Canada). The nonbonded interactions were calculated by using the AMBER force field ${ }^{[21]}$ with a cut-off distance of $8 \AA$. The hydration energy was calculated by using the implicit solvent method. ${ }^{[22]}$ Electrostatic interactions were calculated by using the distance-dependent dielectric function $\varepsilon=4 \mathrm{r}$ where $(r)$ is the atom-atom distance. No specific energy terms were used for cation- $\pi$ interactions, which were accounted for with partial negative charges at the aromatic carbons. ${ }^{[23]}$ Bond lengths and valent angles were assigned standard values. Atomic charges at ligands were calculated by using the AM1 method in the MOPAC program. For each ligand, 100 starting conformations were generated by randomizing torsion angle values. The Monte Carlo minimization (MCM) method ${ }^{[24]}$ was used to optimize the structures. MCM of each model was performed until 600 consecutive energy minimizations did not decrease the energy of the apparent global minimum. For statistical analysis, the 1000 lowest energy conformations were selected.

\section{Acknowledgements}

Technical assistance of Ms. Uraiwan Ngamrabiab Adamsen and Ms. Birgitte Simonsen is gratefully acknowledged.

\section{Keywords: Glutamate receptors · Ion channels · Natural products - Polyamine toxins - Solid-phase synthesis}

[1] A. T. Eldefrawi, M. E. Eldefrawi, K. Konno, N. A. Mansour, K. Nakanishi, E. Oltz, P. N. R. Usherwood, Proc. Nat. Acad. Sci. US A 1988, 85, 49104913.

[2] W. Spanjer, T. E. May, T. Piek, N. Dehaan, Comp. Biochem. Physiol. CPharmacol. Toxicol. Endocrin. 1982, 71, 149-157.

[3] T. F. Andersen, D. B. Tikhonov, U. Bolcho, K. Bolshakov, J. K. Nelson, F. Pluteanu, I. R. Mellor, J. Egebjerg, K. Strømgaard, J. Med. Chem. 2006, 49, 5414-5423.

[4] I. R. Mellor, T. J. Brier, F. Pluteanu, K. Strømgaard, A. Saghyan, N Eldursi, M. J. Brierley, K. Anderson, J. W. Jaroszewski, P. KrogsgaardLarsen, P. N. R. Usherwood, Neuropharmacol. 2003, 44, 70-80.

[5] S. Frølund, A. Bella, A. S. Kristensen, H. L. Ziegler, M. Witt, C. A. Olsen, K. Strømgaard, H. Franzyk, J. W. Jaroszewski. J. Med. Chem. 2010, 53, 7441-7451.

[6] C. A. Olsen, I. R. Mellor, P. Wellendorph, P. N. R. Usherwood, M. Witt, H. Franzyk, J. W. Jaroszewski. ChemMedChem 2006, 1, 303-305.

[7] I. R. Mellor, Fut. Med. Chem. 2010, 2, 877-891.

[8] N. Anis, S. Sherby, R. Goodnow, M. Niwa, K. Konno, T. Kallimopoulos, R. Bukownik, K. Nakanishi, P. Usherwood, A. Eldefrawi, M. Eldefrawi, J. Pharm. Exper. Ther. 1990, 254, 764-773.

[9] M. Bruce, R. Bukownik, A. T. Eldefrawi, M. E. Eldefrawi, R. Goodnow, T. Kallimopoulos, K. Konno, K. Nakanishi, M. Niwa, P. N. R. Usherwood, Toxicon 1990, 28, 1333-1346.

[10] M. R. Jørgensen, C. A. Olsen, I. R. Mellor, P. N. R. Usherwood, M. Witt, H. Franzyk, J. W. Jaroszewski, J. Med. Chem. 2005, 48, 56-70.

[11] K. Strømgaard, I. R. Mellor, K. Andersen, I. Neagoe, F. Pluteanu, P. N. R. Usherwood, P. Krogsgaard-Larsen, J. W. Jaroszewski, Bioorg. Med. Chem. Lett. 2002, 12, 1159-1162.

[12] P. T. Brackley, D. R. Bell, S. K. Choi, K. Nakanishi, P. N. Usherwood, J. Pharmacol. Exp. Ther. 1993, 266, 1573-1580. 
[13] a) D. Jönsson. Tetrahedron Lett. 2002, 43, 4793-4796; b) T. Kan, H. Kobayashi, T. Fukuyama. Synlett 2002, 8, 1338-1340; c) C. A. Olsen, H. Franzyk, J. W. Jaroszewski, Synthesis (Stuttgart) 2005, 2631-2653; d) M. Méret, S. Bienz, Eur. J. Org. Chem. 2008, 5518-5525; e) P. Bisegger, N. Manov, S. Bienz, Tetrahedron 2008, 64, 7531-7536; f) F. Hahn, U. Schepers, J. Comb. Chem. 2008, 10, 267-273; F. Hahn, U. Schepers, Synlett 2009, 17, 2755-2760.

[14] V. K. Reddy, A. Valasinas, A. Sarkar, H. S. Basu, L. J. Marton, B. Frydman, J. Med. Chem. 1998, 41, 4723-4732.

[15] A. I. Khalaf, A. R. Pitt, M. Scobie, C. J. Suckling, J. Urwin, R. D. Waigh R. V. Fishleigh, S. C. Young, W. A. Wylie, Terahedron 2000, 56, 52255239.

[16] a) F. Wang, S. Manku, D. G. Hall, Org. Lett. 2000, 2, 1581-1583; b) C. A. Olsen, M. Witt, J. W. Jaroszewski, H. Franzyk, J. Org. Chem. 2004, 69, 6149-6152.

[17] M. Green, J. Berman, Tetrahedron Lett.1990, 31, 5851-5852.

[18] P. Wellendorph, J. W. Jaroszewski, S. H. Hansen, H. Franzyk, Eur. J. Med. Chem. 2003, 38, 177-122.

[19] H. Kromann, S. Krikstolaityte, A. J. Andersen, K. Andersen, P. Krogsgaard-Larsen, J. W. Jaroszewski, J. Egebjerg, K. Stromgaard, J. Med. Chem. 2002, 45, 5745-5754.
[20] D. B. Tikhonov, I. R. Mellor, P. N. Usherwood, Biophys. J. 2004, 87, 159170.

[21] a) S. J. Weiner, P. A. Kollman, D. A. Case, U. C. Singh, C. Ghio, G. Alagona, S. Profeta, P. Weiner, J. Am. Chem. Soc. 1984, 106, 765; b) S. J. Weiner, P. A. Kollman, D. T. Nguyen, D. A. Case, J. Comput. Chem 1986, 7, 230-252.

[22] T. Lazaridis, M. Karplus, Proteins 1999, 35, 133-152.

[23] I. Bruhova, D. B. Tikhonov, B. S. Zhorov, Mol. Pharmacol. 2008, 74, 1033-1045.

[24] Z. Li, H. A. Scheraga, Proc. Natl. Acad. Sci. U S A 1987, 84, 6611-6615.

Received: ((will be filled in by the editorial staff))

Published online: ((will be filled in by the editorial staff)) 
Entry for the Table of Contents (Please choose one layout)

Layout 1:

\section{FULL PAPERS}

In the search for improved inhibitors of GluA1flop AMPA receptors - a question is "may incorporation of cyclopropane moieties be beneficial and what configuration is superior cis or trans?" Synthesis, test and modelling of four analogues revealed the structure-activity features of this unprecedented subclass of inhibitors.
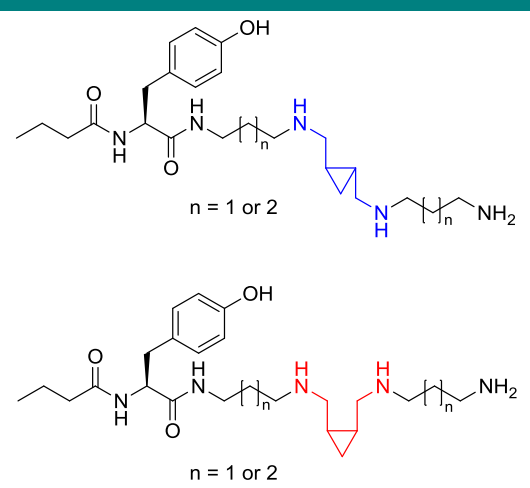

Henrik Franzyk, John W. Grzeskowiak, Denis B. Tikhonov, Jerzy W. Jaroszewski, and lan R. Mellor*

Page No. - Page No.

The Effects of Conformational Constraints in the Polyamine Moiety of Philanthotoxins on AMPAR Inhibition

Layout 2:

FULL PAPERS

((Insert TOC Graphic here))
((Author(s), Corresponding Author(s)*)

Page No. - Page No.

((Title))

((Text for Table of Contents)) 